\title{
》MUSICIANS CONSIDER THEMSELVES PEACEMAKERS.« DIE US-AMERIKANISCHE JAZZSZENE UND DER 11. SEPTEMBER
}

\author{
Bernd Hoffmann und Karsten Mützelfeldt
}

Im Gedenken an Udo Kläs

\section{Was die Welt mitbekam...}

Beim Durchblättern der in der Bundesrepublik Deutschland in den beiden letzten Monaten des Jahres 2001 erschienenen Jazz-Fachpresse fallen nur wenige verstreute Spuren ins Auge: keine essayartigen Überlegungen zum recht ambivalenten Verhältnis von Jazz und Gesellschaft, eher das Notieren diverser Begleitumstände der Attentate: Hier die Information, dass in New York alle Jazzclubs nach den Anschlägen geschlossen haben (Milkowski 2001), dort die Überlegungen zur möglichen Absage eines deutschen Jazzfestivals, da beteiligte Musiker aus den USA nicht einreisen können (Osterhausen 2001). In der Tat liegt der Zeitpunkt der Veröffentlichungen von Zeitschriften wie Jazzpodium, Jazzthing und Jazzthetik noch im Rezeptionsschatten der Ereignisse des 11. Septembers.

Zeitgleich produzierten einige Jazzmusikerinnen und Jazzmusiker primär für den US-amerikanischen Musikmarkt themenbezogene Alben mit Kompositionen und Improvisationen, die aus Anlass des 11. Septembers entstanden waren. Beachtenswert ist dabei die Orientierung an der historischen Klangfarbe der Spiritual Songs des 18. und frühen 19. Jahrhunderts (Hoffmann 1998) vor allem in der Form der Songthemen, die die Grundlage für ihre Improvisationen bilden. Die melodischen und harmonischen Wendungen der religiös orientierten Sorrow Songs und Spiritual Songs finden sich beispielsweise auf dem Album My America des in den USA lebenden Pianisten Monty Alexander. Zwölf populäre Songs der 1920er bis 1960er Jahre werden in verschiedenen Triobesetzungen gespielt: Jazz Standards, Soul- und Funk- 
Themen, ein farbiges Repertoire der American Songs. Das letzte Stück des Albums, »The Battle Hymn Of The Republic «, verwendet gar Liedgut aus der Zeit des US-amerikanischen Bürgerkriegs. ${ }^{1}$ Schließlich wird kurz die USamerikanische Nationalhymne »The Star-Spangled Banner« zitiert. Diese Hymne, die auch der weiße Bassist Charlie Haden im solistisch gehaltenen und einleitenden Improvisationsteil seines Albums American Dreams spielt, basiert ebenfalls auf einem Song des 18 . Jahrhunderts. ${ }^{2}$ Auch im zentralen Werk des Albums Looking For America der Pianistin und Komponistin Carla Bley, einer fünfsätzigen, rund 22 Minuten dauernde Suite »The National Anthem« für Big Band, bestimmt der Hymnenton die Klangfarbe. Schließlich setzt der Pianist D.D. Jackson in seinem Konzeptalbum Suite For New York konsequent auf den alten Spiritualton, etwa in Kompositionen wie »Hopes And Dreams« oder »Brooklyn Lullaby«. Gemeinsam ist dieser eher zufälligen Auswahl von in Deutschland vertriebenen Alben auch die Covergestaltung, in der immer wieder die US-amerikanische Flagge zitiert wird.

In den Monaten nach den Attentaten schienen sich die Ereignisse durch permanente mediale Präsenz und beständige Wiederholungen von Bildern einschlagender Flugzeuge zu anonymisieren. Erst die mediale Darstellung biographischer Momente (Alexander/Baars 2002; Naudet/Naudet 2002), die Dokumentation einzelner Twin Towers-Schicksale verwandelt die Anonymität der terroristischen Anschläge in ergreifende Geschichten von der Zerstörung menschlichen Lebens. Der vorliegende Text stützt sich auf Interviews mit neun US-amerikanischen JazzmusikerInnen oder ImprovisatorInnen, die in ihren biographisch gefärbten Äußerungen von ganz unterschiedlichen Erfahrungen und Erlebnissen berichten (vgl. die Liste der Interviews ${ }^{3}$ ). Die zeitliche Nähe zum Unglückstag bestimmt dabei die Emotionalität der

1 Die Melodie der »Battle Hymn Of The Republic « basiert auf einem anonymen Camp Meeting Tune des frühen 19. Jahrhunderts, den Unionssoldaten zum Tode von John Brown mit einem neuen Text versehen hatten. Julia W. Howe wiederum veröffentlichte 1862 in der Publikation Atlantic Monthly einen patriotischen Text, der mit der wiederholten Refrainzeile "Glory, Glory Hallelujah" endet.

2 Um 1775 komponierte John Stafford Smith »The Anacreontic Song « für die Londoner Anacreontic Society. Als morgendlicher musikalischer Salut zur Flaggenparade übernahm die US-amerikanische Marine nach 1889 diese Komposition mit verändertem Text. Anfang der 30er Jahre des 20. Jahrhunderts wurde sie vom Kongress als »The Star-Spangled Banner« zur offiziellen Hymne der USA erklärt.

3 Die Auswahl dieser MusikerInnen ergibt sich durch die Zufälligkeit ihrer entsprechenden europäischen Tourneen und Tourneeangebote in den Jahren 2001 bis 2004. Ihre Äußerungen dürfen nur als Einzelmeinungen zur Problematik des 11. Septembers 2001 verstanden werden. Den MusikerInnen wurde kein systematisierter Fragenkatalog vorgelegt. 
Schilderungen, aber eine Reflexion über politische Konsequenzen aus den Anschlägen ist sowohl direkt nach dem 11. September wie auch Jahre später festzustellen. Neben dieser politischen Fragestellung aber dominiert in allen Interviews die Vorstellung der MusikerInnen, durch künstlerische Tätigkeit den erfahrenen Schmerz gelindert zu haben - sowohl den eigenen als auch den des Publikums.

Im Mittelpunkt dieser eher als Dokumentation verstandenen Ausarbeitung sollen die unterschiedlichen Aussagen der MusikerInnen zu Motivbündeln geschnürt werden, deren kleinster gemeinsamer Nenner vom Vibraphonisten Mike Mainieri formuliert wird: »I'm not a politician, but musicians consider themselves peacemakers« (Mainieri, Interview 2001).

\section{Improvisations-Freiheiten}

Die Betroffenheit des Moments schlägt sich in nahezu allen Interviews nieder. Sie wird umgedeutet und vor allem verstanden als ein besonderer Impuls, der musikalische Kreativität freisetzt im Sinne einer lebensbejahenden Perspektive. Erste Eindrücke - ob vor Ort in New York oder medial vermittelt - werden bestimmt durch die unmittelbare Gefahrensituation und die Bewältigung der chaotischen Umstände. Verbunden sind diese Impressionen im Angesicht der Terroranschläge mit den Beobachtungen von MusikerInnen, die es aus langer Bühnenerfahrung heraus gewöhnt sind, auf Veränderung des Publikums zu reagieren. Die schwarze Sängerin Cassandra Wilson lässt die ungewöhnliche Situation der Stadt New York und ihrer Bevölkerung nach den Attentaten lebendig werden:

"New York was very, very different. You felt so much closer to the stranger passing by. And eyes met which is rare in New York. People generally just walk past and you don't let the eyes meet. And it's a protection, it's a way, a protective mechanism, I guess. But during those weeks after September 11 people were a lot more willing to share the events in their lives, they were a lot more vulnerable yet still cocky at the same time because New Yorkers will never stop being cocky, that is just a part of the whole New York persona. But you could see a little bit of that armour being released because we were all there together and we were all experiencing this horrible event together, so we took comfort in each other! (Wilson, Interview 2003). ${ }^{4}$

4 Vgl. hierzu auch das Statement von Laurie Anderson in Mützelfeldt 2002. 
Auch der Keyboarder George Duke thematisiert diese besondere, nach innen gekehrte Ungewissheit nach den Anschlägen. Darüber hinaus beschreibt er die Starre seines Konzertpublikums während der Bühnenauftritte:

»When we played there the next, the few days after that, we actually played at this club, it was very strange! You know, normally which would be the first night, which is not only that it is packed, but everybody is like anticipating the music and up - this was the strangest, I almost cancelled the gig because it was strange! People were very sober, no laughing, no smiling, everybody was just sort of sitting there and, it just goes to show you what the power of music can do! (Duke, Interview 2003).

Einen Ausweg aus dieser besonders schwierigen Situation benennt der Keyboarder hier ganz direkt und das im Einklang mit den anderen Musikern, die in den Gesprächen zum 11. September primär das persönliche Erleben schildern. Besonders eindringlich beschreiben Kontrabassist Christian McBride und Gitarrist Dominic Miller die Vorbereitungen zu den gemeinsamen Live-Aufnahmen der Sting-CD ... all this time, ein Konzert, das knapp zwei Stunden nach den Attentaten im italienischen Il Palagio gegeben wurde:

"I could never verbally express the shock and terror that everybody felt. So Sting called a meeting and asked us if we feel like performing. And, you know, nobody knew what to say! I mean, it was kinda, first of all, one of the background singers, Janis Pendarvis, you know, she has a nine year old son, and of course, nobody could get through to New York by telephone for maybe a good 24 hours! So I mean, you know, the poor woman! We just felt so much sympathy for, it turned out her son was okay, but, you know, she had a sleepless night without getting in touch with him, so - but after kind of leaning on each other and kind of expressing our feelings we decided to play - not a full show but just, you know, certain songs« (Miller, Interview 2004).

Die starke persönlicher Betroffenheit in diesem Moment wird spürbar, aber auch der Wunsch in einer solchen bedrückenden Situation zu musizieren. Dabei thematisiert aber keiner der befragten Musiker die Überlegung aufgrund der situativen Erfahrung spontan musikalisches Material zu verändern.

"So we felt a collective responsibility to play some music, but we didn't play it with the same bravado or like confidence that we normally would, so it's quite understated that performance. And it was very deep! We were all quite nervous and we were playing quietly and innocently! And I think, it was a fantastic musical experience in my life, but, you know, I share the same feelings with 9/11 than everyone else does!« (Miller, Interview 2004).

Für den Kontrabassisten Christian McBride sind die Erfahrungen dieses Konzertes auch Jahre später noch nicht abgeschlossen. Zwar empfand er nach 
Ende des Konzertes eine besondere Zufriedenheit, dennoch mag er nicht durch das Anschauen der Videoaufzeichnung daran erinnert werden:

"And we did the best we could do, and I mean, that's why we play music, you know! Ultimately this is why we play music: to heal the wounds that a tragedy like that causes! But of course, it was so fresh, it was such a brand new tragedy - I mean, gosh!! Man, I don't like watching the video! You know, as soon as it gets to September 11th, I cut if off cause it's too deep. But, of course, as the night progressed we started to feel a little better and we played a few more songs that we hadn't planned on playing, and after the show was over, man, everybody just kind of bonded, you know, we walked around with the audience and, you know, talked and ultimately it was a victorious night!« (McBride, Interview 2003).

$\mathrm{Ob}$ in der musikalischen Erfahrung der Soloimprovisation Manieris oder in der Gestaltung von Gruppenkonzepten, hier tritt jenes »rollenstereotypische Verhalten « (Hoffmann 1998b: 76) in unterschiedlichen Akzentuierungen zu Tage, das vor allem Jazzmusiker auszuzeichnen scheint: der Glaube an die scheinbar selbstheilenden Kräfte der Improvisation. Auch der deutsche Saxophonist Claudius Valk beschreibt im Zusammenhang mit den Attentaten solche primären, persönlichen Reaktionen:

"Auch wenn es vielleicht etwas romantisierend klingt: Das Erste, was ich gemacht habe, als ich das gehört habe, ich bin in den Proberaum gefahren und habe eine Stunde gespielt. [...] Für mich kann das kein Anlass sein, jetzt inne zu halten und zu sagen, ich, ich kann jetzt nicht spielen, im Gegenteil: Also für mich bedeutet das: Ich muss über ganz viele Dinge in meinem Leben nachdenken und muss versuchen, mit meinen Möglichkeiten die Welt so schön wie möglich zu gestalten und so fair und so liebevoll wie möglich zu gestalten, und dazu gehört für mich Musikmachen, ganz klar« (Valk in Mützelfeld 2001).

Die Worte der Musiker beschreiben, was Paul Berliner als den »emotional impact « (Berliner 1994: 391) in der Prozesshaftigkeit der Improvisation bezeichnet. Dieser musiktherapeutische Faktor scheint im Angesicht des 11. Septembers offenbar mitbestimmend gewesen zu sein für ein Rollenstereotyp des Jazzmusikers und der Jazzmusikerin, das sich deutlich von den Annahmen des Soziologen Howard S. Becker unterscheidet, der in seiner Soziologie abweichenden Verhaltens die Musiker der US-amerikanischen Jazzszene als »Außenseiter« beschreibt (Becker 1981: 92f.). 


\section{Situation in New York}

Die Alben These Times von Mike Stern und 34th N Lex von Randy Brecker müssen als konkrete Reaktion im Sinn einer thematischen Auseinandersetzung verstanden werden. Typisch für diese Kompositionen ist die Verdichtung alltäglicher Situationen zu Songtexten, Titelzeilen oder Kompositionsüberschriften, die eine lang andauernde Tradition im Jazz darstellt. Im Gespräch erklärt Stern den Titel seiner Komposition »Chatter «:

")Chatter is that term they use in, when the chatter-level is, in the States when they say sometimes >the chatter level is high<, they raise the terror alert, you know! Cause, it has got a little bit of that, or it could be meaning >chatter, just talk. But for me, it meant a little bit of that, that it is something very different that we are talking about, the whole new kind of some new terms that are cropping up the last few years (Stern, Interview 2003).

Der Gitarrist wählt den eher indirekten Weg bei der Beschreibung der Terrorangst und den Titel aus einem nach 9/11 entstandenen Vokabular. Im Gegensatz dazu benennt der Titel von Breckers Album 34th N Lex nicht ohne Grund eine geographische Position in der Stadt New York. Seine programmatische Schilderung des Stadtalltags, der sich durch den 11. September stark verändert hat, fokussiert die hieraus resultierenden Wandlungen täglicher Situationen im privaten wie öffentlichen Bereich und ist Sinnbild für Breckers Empfindungen für seine Heimatstadt nach den Attentaten:

»I live on that intersection, 34th ' $n$ ' Lex, and there is a lot of noise. I hear everything from the street and it's like osmosis: it all seeps in, eventually it is kind of don't pay attention but it's always there when I am writing like sirens, busses, people yelling and whizzing by and starts about 7.30 in the morning and it goes till the night and then I can really kind of arrange my thoughts, but every day that stuff is there. [...] Our area is still troublesome, I guess, cause of there is some embassies around and the proximity to the Empire State Building, so we are always getting buzzed. You have to come down for a while, they won't let people deliver stuff in the building anymore if you order a pizza you have to go to the lobby and get it, so it is something we feel every day. Let alone buying gasmasks and duct tape and whatever else they tell you to get, if that would do any good« (Brecker, Interview 2003).

Breckers künstlerische Umsetzung der erlebten Stadtagonie verzichtet konsequent auf assoziative Momente, etwa die musikalische Ausdeutung von Lähmung und Hysterie. Die Hinweise des Trompeters: "I love being in New York [...] and it has a big influence on everything I write (ebd.) beziehen 
sich sowohl auf die Auswahl seiner Mitmusiker, ausschließlich New Yorker, als auch auf aktuelle HipHop-Anklängen, die aus dem urbanen sSoundarchiv des Trompeters stammen. Die kompositorische Anlage bei 34th N Lex, basierend auf früheren konzeptionellen Ideen der Brecker Brothers-Band, zeigt einen stärker jazzorientierten Impuls, durchaus im Sinn einer Akzentuierung und Weiterentwicklung der Vorlagen aus den 1970er-1980er Jahren. Damit wählt der Trompeter eine Konzeption, die - im Gegensatz zu anderen, nach dem 11. September erschienenen Alben (s.o.) - kaum mit nationalem Pathos aufgeladen ist. Breckers Intentionen - das gesellschaftliche Leben New Yorks nach den Attentaten zu thematisieren - werden allerdings erst durch die konkrete Beschreibung der alltäglichen Umstände im vorliegenden Gespräch vermittelt.

\section{Jazz nach dem 11. September}

Als abschließender Aspekt der Interviews sei auf die politischen Reaktionen der Musiker auf den 11. September eingegangen und auf ihre Überlegungen zu den Ursachen der Gewaltakte. Natürlich ist ein Selbstverständnis des Musikers als »peacemaker «à la Mainieri nicht die einzige politische Meinung, jedoch lässt sich auch in keiner Aussage eine Bereitschaft erkennen, die Aggressoren militärisch abzustrafen. Diese auffällig friedfertige Haltung zeichnet sowohl die Gespräche unmittelbar nach den Flugzeugeinschlägen in die Twin Towers aus wie auch die Interviews zwei Jahre danach. Die Statements der Musiker zur Politik der US-amerikanischen Regierung beziehen sich ausnahmslos auf die problematische Situation des Nahen Ostens. Ganz pragmatisch berichtet Randy Brecker (Interview 2003) von seinem erst kürzlich absolvierten Konzert in Israel:

»I am a musician, I wanna play for people and I hope this war work out somehow, but it's a terrible thing, you know, the whole world situation now. But I just go about my business, I went to Israel last month and played a concert there« (Brecker, Interview 2003).

Und der Vibraphonist Mainieri zählt die Krisengebiete der Welt auf:

»The revenge seeks more revenge, right, it's a snowball, it has been going in the Middle East for what else and it's like what is happening in Ireland, right? So I mean, the Afghan people are peaceful people. There are, when I was there, they were wonderful, very open people« (Manieri, Interview 2001).

In die Forderung nach politischer Nachdenklichkeit und Reflexion von Seiten der Regierung stimmen sowohl der Pianist Chick Corea als auch die Sängerin 
Cassandra Wilson ein. Corea fordert Verständnis für die unglücklichen Menschen im Angesicht komplexer politischer Verhältnisse, die politische und gesellschaftliche Umstände zum Terrorismus getrieben haben:

»If you look at that part of the world in the Middle East, they have been suppressed and in slavery for as long as we can remember in our historic times. These people are not happy people. And it begins at a point, where human beings begin to become intolerant toward others, you see? So this modern question of human rights, I feel, is the correct subject to address, to address the subject in terms of war and bombs and retaliation and - of course, these people, these murderers must be found, they must be brought to justice but then to turn it into some kind of a blind target of groups, ethnic groups or religious groups, it's the historic way to destroy a civilisation « (Corea, Interview 2001).

Cassandra Wilson geht noch einen Schritt weiter und befürwortet, dass sich die Kulturen des Westens und des Ostens Kennen und Verstehen lernen sollen:

"I think, it's really important to at least put your foot on the earth there, you know, just once, once in your life and, and, to connect with people, look them in the eye and see them on their own terms in their own communities, in their own world « (Wilson, Interview 2003).

Inwieweit die Politisierung durch 9/11 innerhalb der US-amerikanischen Jazzszene zu einer perspektivischen Verschiebung ihres gesellschaftlichen Selbstverständnisses - vor allem unter afro-amerikanischen MusikerInnen geführt hat, muss sich in den kommenden Jahren zeigen. 


\section{Literatur}

Alexander, Barbara / Baars, Gerald (2002). »Die durch die Hölle gingen - Der zweite Geburtstag: Überleben am 11. September.«Fernsehreportage des Westdeutschen Rundfunks, Köln, gesendet am 29. August (WDR).

Becker, Howard S. (1981). Außenseiter. Zur Soziologie abweichenden Verhaltens. Frankfurt/M.: Fischer Taschenbuch Verlag [orig. Outsiders: Studies in the Sociology of Deviance. London/New York: The Free Press of Glencoe 1963].

Berliner, Paul F. (1994). Thinking in Jazz. The Infinite Art of Improvisation. Chicago: University of Chicago Press.

Hoffmann, Bernd (1998). "Sacred Singing. «In: Die Musik in Geschichte und Gegenwart. Sachteil Bd. 8. Hg. v. Ludwig Finscher. Kassel, Stuttgart: Bärenreiter/ Metzler (2. Aufl.), Sp. 793-830.

Mandel, Howard (2003). Album Details: D.D. Jackson - Suite For New York. CD, Just 188-2 LC 10584.

Milkowski, Bill (2001). »Notes from New York.« In: Jazzthing, Nr. 41 (Nov. 2001 Jan. 2002), S. 6.

Mützelfeldt, Karsten (2001). »Jazzfacts - Jazzfestival Viersen 2001.« Rundfunksendung Deutschlandfunk, Köln, gesendet am 21. September.

Mützelfeldt, Karsten (2002). »Recorded September 11th. « Rundfunksendung WDR 3, Köln, gesendet am 11. September (19.30-20.00 Uhr).

Naudet, Gedeon / Naudet, Jules (2002). "11. September - Die letzten Stunden im World Trade Center. « Fernsehreportage des Westdeutschen Rundfunks, Köln, gesendet am 11. September (ARD).

Osterhausen, Hans-Jürgen von (2001). »15. Int. Jazzfestival Viersen - Trotz Absagen ein hochkarätiges Programm.« In: Jazzpodium 50, Nr. 12 (Dezember), S. 35.

\section{Interviews}

Brecker, Randy Köln, 7. März 2003.

Corea, Chick

Hamm, 28. September 2001.

Duke, George

Köln, 24. September 2003.

Mainieri, Mike

Viersen, 14. September 2001.

McBride, Christian

Berlin, 3. November 2002.

Miller, Dominic

Köln, 7. Januar 2004.

Stern, Mike

Köln, 15. August 2003.

Wilson, Cassandra

Köln, 25. September 2003.

\section{Auswahldiskographie: Jazz und 9/11}

Monty Alexander (2002). »The Battle Hymn Of The Republic.« Auf: My America. CD, Telarc CD 83552 LC.

Carla Bley (2003). »The National Anthem« [fünfteilige Suite]. Auf: Looking for America. CD, Watt/31 067791-2 LC 04438.

Randy Brecker (2003). »34th N Lex.« Auf: 34th N Lex. CD, ESC Records 03684 LC 01263. 
Kenny Garrett (2002). »Happy People.« Auf: Happy People. CD, Warner Music 9362 47754-2 LC 00392.

Charlie Haden (2002). "American Dreams. A Auf: American Dreams. CD, Universal Music 064096-2 LC 00383.

D.D. Jackson (2003). »Hope and Dreams. « Auf: Suite For New York. CD, Just 188-2 LC 10584.

Mike Stern (2004). "These Times. "Auf: These Times. CD, ESC Records 4911 LC 01263.

Sting (2001). ... all this time. CD, A\&M Records 493156-2 LC 00485.

Jens Winther Group (2001). "Twin Towers. "Auf: walk the walk talk the talk. CD, Stunt Records 01172 LC 9237 [Der Titel des dänischen Trompeters Jens Winther wurde vor dem 11. September 2001 eingespielt, das Album aber erst nach den Anschlägen veröffentlicht. Winther beließ seine Komposition trotz Vorbehalten der Schallplattenfirma auf dem Album (vgl. Interview der Autoren mit Winther am 29. August und 14.Dezember 2001 in Köln)].

\begin{abstract}
This article discusses the individual feelings and opinions of eight US-American jazz musicians (Brecker, Corea, Duke, Mainieri, Mc Bride, Miller, Stern and Wilson) in the wake of $9 / 11$, which have been interviewed by the authors some time after the attacks on the World Trade Center. The musicians describe how the attacks have influenced their music and changed the atmosphere of their concerts. Most of them are convinced of the healing power of music and improvisation. Musicians living in New York mention the changes in the city after $9 / 11$ and how the new situation has influenced their work. Jazz musicians obviously still see their role in society as peacemakers and express their hope for a better understanding of cultures in East and West.
\end{abstract}

